\title{
Sugar apple seedling production as a function of substrates and slow-release fertilizer
}

\author{
Scheila Antunes Amorim $(1)$, Augusto Miguel Nascimento Lima*(-),

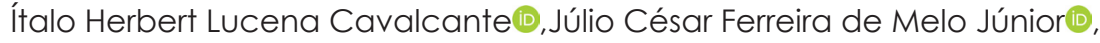 \\ Dayanne do Nascimento Dias@- Talison Sousa da Silva@ Kátia Araújo da Silva@
}

Federal University of São Francisco Valley, Petrolina, Brazil

*Corresponding author, e-mail: augusto.lima@univasf.edu.br

\begin{abstract}
There is still a lack of studies on the effect of slow-release fertilizers and substrates on the production of highquality sugar apple seedlings. In this context, the present study aimed to evaluate the quality and biomass of sugar apple seedlings grown in organic substrates at doses of slow-release fertilizer. The experimental design was randomized blocks in split-plot scheme, with four replicates and eleven plants per plot. Substrates were evaluated in the plots (fresh sugarcane bagasse; enriched sugarcane bagasse; coconut powder; commercial organic substrate Tropstrato $^{\circledR}$ ), whereas the doses of the slow-release fertilizer Osmocote ${ }^{\circledR}$ were evaluated in the subplots $\left(0 ; 3 ; 6 ; 9 ; 12\right.$ and $15 \mathrm{~kg} \mathrm{~m}^{-3}$ of substrate). Substrates and slow-release fertilizer doses had effect on the formation of sugar apple seedlings. The effect of slow-release fertilizer is influenced by the substrate used in the formation of sugar apple seedlings. The substrate coconut powder showed the best performance for E\%, NL and LAI in sugar apple plants, which reinforces its recommendation to be used in seedling production. For the studied conditions, based on the DQI, we recommend coconut powder associated with the slow-release fertilizer dose of $9 \mathrm{~kg} \mathrm{~m}^{-3}$ to produce sugar apple seedlings.
\end{abstract}

Keywords: Annona squamosa L., fertilization, organic residues

\section{Introduction}

Popularly known as 'pinha', 'ata' or 'fruta-doconde', sugar apple (Annona squamosa L.) is one of the main Annonaceae species cultivated in Brazil and stands out for its potential of commercialization in the internal market, with great prospects for exportation (Dantas et al., 2010).

In the São Francisco Valley, irrigated fruticulture stands out as the main activity of the agribusiness. Nevertheless, despite having great agroindustrial potential, it faces problems with scarcity of good-quality, pathogen-free seedlings to plant new orchards (Melo Júnior et al., 2014).

Carrijo et al. (2002) report that the good physical properties, lack of reaction with nutrients from fertilization and long durability without alteration of physical characteristics, as well as the abundance of raw material, causes the green coconut fiber to be a substrate hardly overcome by other type of substrate, either mineral or organic. Dutra et al. (2012) claim that sugarcane bagasse has adequate chemical composition, capable of promoting good plant development and its use contributes to the reduction of its accumulation in the environment.

Adequate nutritional balance is fundamental for the formation of productive orchards. Fertilization must provide the sufficient quantity of nutrients for adequate quality and growth of the seedlings, besides replenishing nutrients lost through leaching (Klooster et al., 2012). Associated with a good substrate, Delamerlina et al. (2014) recommend the use of quality fertilizers, at adequate doses and with slow release. That slow or controlled-release fertilizers can be used in the fertilization of fruit seedlings, since they promote a synchronism between the release of nutrients and the requirements for plant growth and development, which renders 
unnecessary the split application of other sources, thus avoiding the occurrence of nutritional deficiency and losses through leaching, which consequently reduces costs with execution (Costa et al., 2011). Among these fertilizers, a prominent one is Osmocote ${ }^{\circledR}$, which has been widely employed nowadays in the production of seedlings in containers (Elli et al., 2013).

Evaluating the influence of various substrates and two fertilizer formulations on the development of yellow passion fruit seedlings, Silva et al. (2001) claim that Osmocote ${ }^{\circledR}$ promoted the greatest development of the seedlings, followed by 4-14-8 NPK. The use of slow-release fertilizer proved to be efficient in the production of seedlings of citrus (Almeida et al., 2012), avocado (Costa et al., 2011), pineapple (Freitas et al., 2011), banana (Rodrigues et al., 2019), papaya (Serrano et al., 2010) and tamarind (Santos et al., 2018). For sugar apple, there is a lack of studies using slow-release fertilizers in different organic substrates. The hypothesis of this study was that the quality and growth of sugar apple seedlings is influenced by the different organic substrates and doses of slow-release fertilizer.

The present study aimed to evaluate the quality and biomass of sugar apple seedlings grown in tubes using different organic substrates and doses of slowrelease fertilizer.

\section{Material and Methods}

The study was conducted in two cycles of sugar apple (Annona squamosa L.) seedling production, the first one from May 29 to September 15, 2015, and the second one from March 18 to July 4, 2016, in a screen house $150 \%$ shading), situated in Petrolina city, Pernambuco (PE) state, Brazil (09¹9'35' ' S, 40³2' 53' ' W; 370 m). According to Köppen's classification, the region has BSWh' climate, dry and very hot steppe climate (Alvares et al., 2013). Monthly means of the climatic variables temperature, relative air humidity and rainfall recorded in Petrolina-PE along the experiment were $26.32^{\circ} \mathrm{C}, 56.38 \%$ and $8 \mathrm{~mm}$, respectively (Laboratory of Meteorology/UNIVASF).

The experimental design was randomized blocks in split-plot scheme, with four replicates and eleven plants per plot. Plots were represented by four organic substrates: fresh sugarcane bagasse; enriched sugarcane bagasse lobtained by composting fresh sugarcane bagasse, filter cake, sludge from sugarcane washing and vinasse); coconut powder; and, commercial substrate Tropstrato ${ }^{\circledR}$. Each plot was divided into six subplots, represented by the doses of the slow-release fertilizer Osmocote Plus ${ }^{\circledR}$ (NPK: 15-9-12): 0, 3, 6, 9, 12 and $15 \mathrm{~kg}$ $\mathrm{m}^{-3}$. The manufacturer's recommended dose of the slow- release fertilizer Osmocote Plus ${ }^{\circledR}$ (NPK: 15-9-12) is $9 \mathrm{~kg} \mathrm{~m}^{-3}$. The fertilizer Osmocote Plus ${ }^{\circledR}$ 15-9-12 contains minerals coated with a membrane that allows a slow supply, for three to four months, and is composed of $15 \%$ of nitrogen (N), 9\% of phosphorus (P2O5), 12\% of potassium (K2O), 1.3\% of magnesium (Mg), $5.9 \%$ of sulfur (S), $0.02 \%$ of boron (B), $0.05 \%$ of copper (Cu), $0.46 \%$ of iron (Fe), $0.02 \%$ of manganese (Mn), $0.02 \%$ of molybdenum (Mo) and $0.05 \%$ of zinc (Zn). The composition of the commercial substrate Tropstrato ${ }^{\circledR}$ is based on pine bark, peat and expanded vermiculite.

The substrates were subjected to physical and chemical characterization (Table 1). Physical characteristics were determined using the methods described in the Normative Instruction $n^{\circ} 17$, May 21, 2007 (MAPA, 2007). Chemical characteristics (macroand micronutrients) were determined according to the methodology described by Malavolta et al. (1997).

The substrates were arranged on 16 benches (tanks), with dimensions of $1.2 \times 0.6 \times 0.8 \mathrm{~m}(\mathrm{~L} \times \mathrm{W} \times \mathrm{H})$, and subplots consisted of doses of the slow-release fertilizer Osmocote Plus ${ }^{\circledR}$. Each fertilizer dose was applied in three rows with eleven plants, alternately arranged to guarantee a minimum spacing of $10 \mathrm{~cm}$ between plants, representing the subplots.

The experiment was conducted in a screened house (50\% attenuation of short-wave solar radiation). For sowing, each substrate and the slow-release fertilizer were manually mixed using a shovel and a hoe. The tubes (0.131 $\mathrm{m}$ high and $180 \mathrm{~cm}^{3}$ volume) were manually filled with the mixture (substrate + Osmocote $^{\circledR}$ ) and arranged side by side on trays. The substrate coconut powder was subjected to washing before sowing to eliminate the excess of $\mathrm{Na}^{+}$ions.

Seeds were obtained from fruits commercialized in the Mercado do Produtor in Juazeiro city, Bahia state, Brazil. Ripe sugar apples were manually pulped to remove the seeds, which were subsequently soaked in water for $24 \mathrm{~h}$.

Seeds were planted at depth of approximately $1.0 \mathrm{~cm}$. After that, vermiculite was added to the substrate and the first irrigation was applied using a watering can.

Emergence percentage was evaluated at 40 days after sowing (DAS), quantifying the number of germinated seedlings.

Irrigation was applied using the sub-irrigation system, in which the tubes were partially immersed in water for $5 \mathrm{~min}$. Two irrigations were daily applied, at 9 $\mathrm{h}$ and $15 \mathrm{~h}$, to guarantee full moistening of the substrate. The experiment was monitored and no phytosanitary 
problem was observed. Thinning was performed at 45 DAS, when the seedlings exhibited two vigorous true leaves, leaving the most developed one.

The last evaluation of the experiment was performed at 105 DAS. To evaluate the effects of treatments on the formation of sugar apple seedlings, the following variables were determined: I) Number of leaves; II) Plant height $(\mathrm{PH}, \mathrm{cm})$ : measured from the substrate level to the insertion of the last leaf, using a millimeter ruler; III) Stem diameter (SD, mm): measured with a digital caliper (Pantec ${ }^{\circledR}, 0.01 \mathrm{~mm}$ resolution) at height of $1.0 \mathrm{~cm}$.

Table 1. Chemical and physical characteristics of the substrates fresh sugarcane bagasse, enriched sugarcane bagasse, coconut powder and Tropstrato ${ }^{\circledR}$ used in the experiment

\begin{tabular}{|c|c|c|c|c|}
\hline Properties & Sugarcane bagasse & Enriched sugarcane bagasse & Coconut powder & Tropstrato ${ }^{\circledR}$ \\
\hline $\mathrm{pH}$ & 7.1 & 7.9 & 5.8 & 6.0 \\
\hline $\mathrm{ECa}\left(\mathrm{dS} \mathrm{m}^{-1}\right)$ & 0.9 & 1.1 & 0.4 & 0.5 \\
\hline$C\left(g ~ k g^{-1}\right)$ & 522 & 146 & 350 & 18 \\
\hline$N\left(g \mathrm{~kg}^{-1}\right)$ & 3.8 & 8.4 & 5.8 & 3.8 \\
\hline$P\left(g ~ k g^{-1}\right)$ & 2.0 & 6.6 & 2.4 & 3.1 \\
\hline$K\left(g k^{-1}\right)$ & 6.5 & 9.0 & 10.5 & 6.5 \\
\hline $\mathrm{Ca}\left(\mathrm{g} \mathrm{kg}^{-1}\right)$ & 3.2 & 22.8 & 5.7 & 9.2 \\
\hline $\operatorname{Mg}\left(g_{k g}{ }^{-1}\right)$ & 0.6 & 3.9 & 1.4 & 14.0 \\
\hline $\mathrm{Na}\left(\mathrm{g} \mathrm{kg}^{-1}\right)$ & 0.2 & 0.5 & 0.7 & 0.4 \\
\hline $\mathrm{Fe}\left(\mathrm{mg} \mathrm{kg}^{-1}\right)$ & 841 & 17.620 & 780 & 7.180 \\
\hline $\mathrm{Mn}\left(\mathrm{mg} \mathrm{kg}^{-1}\right)$ & 36 & 592 & 27 & 164 \\
\hline $\mathrm{Zn}\left(\mathrm{mg} \mathrm{kg}^{-1}\right)$ & 14 & 110 & 25 & 32 \\
\hline$B\left(\mathrm{mg} \mathrm{kg}^{-1}\right)$ & 5 & 14 & 24 & 13 \\
\hline $\mathrm{C} / \mathrm{N}$ & $137 / 1$ & $17 / 1$ & $60 / 1$ & $5 / 1$ \\
\hline OMb $\left(\mathrm{g} \mathrm{kg}^{-1}\right)$ & 900 & 252 & 604 & 30.4 \\
\hline CECc $\left(\mathrm{mmolc} \mathrm{dm}^{-3}\right)$ & 144.1 & 161.1 & 383.5 & 292.6 \\
\hline Dsubd $\left(\mathrm{kg} \mathrm{m}^{-3}\right)$ & 518.6 & 644.5 & 504.6 & 538.1 \\
\hline $\operatorname{TPe}(\%)$ & 26 & 32 & 73 & 43 \\
\hline Mostuire (\%) & 12 & 15 & 83 & 40 \\
\hline
\end{tabular}

After biometry, plants were divided into roots and shoots, to determine the following variables: I) Root volume $\left(\mathrm{RV}, \mathrm{cm}^{3}\right)$ : measured in a graduated cylinder (Basso, 1999); II) Root dry matter (RDM) and shoot dry matter (SDM) (g): obtained through the method of drying in a forced-air oven at $65^{\circ} \mathrm{C}$ until constant weight, with subsequent weighing on analytical scale $(0.0001 \mathrm{~g})$ (Silva \& Queiroz, 2002); and III) Leaf area index (LAI, $\left.\mathrm{cm}^{2}\right)$ : measured in two plants per subplot, by removing the leaves and placing them on a white paper. After that, they were photographed and subjected to the software QUANT v.1.0.1 (Vale et al., 2001).

Total dry matter (TDM) was estimated based on the values of RDM and SDM. In addition, the ratio between shoot dry matter and root dry matter (S/R) and the Dickson quality index (DQI) were also calculated. DQI was used to evaluate seedling quality according to the treatments and refers to the relationships of the morphological growth characteristics TDM, SDM, RDM, PH and SD, according to the following equation 1 (Dickson et al., 1960):

$$
\mathrm{DQI}=\frac{\mathrm{TDM}}{\mathrm{PH}+\frac{\mathrm{SDM}}{\mathrm{RDM}}} \quad \text { equation } 1
$$

Where: $\mathrm{DQI}=$ Dickson quality index $\left(\mathrm{g} \mathrm{mm} \mathrm{cm-1}^{-1}\right.$; $\mathrm{TDM}=$ total dry matter $(\mathrm{g}) ; \mathrm{PH}=$ plant height $(\mathrm{cm}) ; \mathrm{SD}$ = stem diameter (mm); SDM = shoot dry matter (g); and $\mathrm{RDM}=$ root dry matter (g).

The data were subjected to analysis of variance by $F$ test at 0.01 and 0.05 probability levels, and means were compared by Scott-Knott test to detect significant effects between the different substrates and doses of Osmocote Plus ${ }^{\circledR}$ (Borges \& Ferreira, 2003). Significant interactions were subjected to regression analysis and correlations were made between all dependent variables.

\section{Results}

There was significant interaction between substrate compositions and doses of the slow-release fertilizer Osmocote Plus ${ }^{\circledR}$ for all variables (Table 2).

Slow-release fertilizer application in the substrates significantly increased the number of leaves, plant height, stem diameter, leaf area, shoot, root and total dry matter and root volume in sugar apple seedlings, in comparison to the control (without fertilization). There were different responses to the doses and their interactions with the substrates (Figures 1 and 2). For the means of stem diameter, it was not possible to fit any regression model. 
Table 2. Means and $F$ value of emergence percentage (E\%), number of leaves (NL), plant height (PH), stem diameter (SD), shoot dry matter (SDM), root dry matter (RDM), total dry matter (TDM), root volume (RV), leaf area index (LAI), shoot/root ratio (S/R) and Dickson quality index (DQI) in sugar apple seedlings as a function of different substrates and doses of slow-release fertilizer

\begin{tabular}{|c|c|c|c|c|c|c|c|c|c|c|c|}
\hline Substrate & $\begin{array}{l}\mathrm{E} \\
\%\end{array}$ & $\begin{array}{c}\mathrm{NL} \\
--\end{array}$ & $\begin{array}{l}\mathrm{PH} \\
\mathrm{cm}\end{array}$ & $\begin{array}{l}\mathrm{SD} \\
\mathrm{mm}\end{array}$ & SDM & $\begin{array}{c}\text { RDM } \\
-9 \\
\end{array}$ & TDM & $\begin{array}{l}\mathrm{RV} \\
\mathrm{cm}^{3}\end{array}$ & $\begin{array}{l}\mathrm{LAl} \\
\mathrm{cm}^{2}\end{array}$ & $\begin{array}{l}S^{-1} R^{-1} \\
g^{-1}\end{array}$ & $\begin{array}{c}\text { DQI } \\
\mathrm{g} \mathrm{mm} \mathrm{cm}^{-1}\end{array}$ \\
\hline Fresh sugarcane bagasse & $90.15 a$ & $6.39 \mathrm{~d}$ & $8.50 \mathrm{~d}$ & $2.55 \mathrm{C}$ & $0.45 \mathrm{~d}$ & $0.33 \mathrm{c}$ & $0.78 \mathrm{~d}$ & $1.17 \mathrm{C}$ & $44.90 \mathrm{c}$ & $1.39 \mathrm{a}$ & $0.16 \mathrm{c}$ \\
\hline nriched sugarc & 89.01 a & $8.17 b$ & $9.99 \mathrm{~b}$ & $3.10 a$ & $0.69 \mathrm{~b}$ & $0.50 \mathrm{~b}$ & $\Rightarrow$ & $1.44 \mathrm{~b}$ & $66.94 \mathrm{~b}$ & $1.38 \mathrm{a}$ & $0.25 b$ \\
\hline Coconut & $87.31 \mathrm{a}$ & $8.59 a$ & 10.32 a & $3.16 a$ & $0.81 a$ & $0.72 a$ & $1.53 a$ & $1.92 \mathrm{a}$ & $77.65 \mathrm{a}$ & $1.20 \mathrm{~b}$ & $0.35 a$ \\
\hline Trops & $81.25 b$ & $7.50 \mathrm{c}$ & $9.38 \mathrm{c}$ & $2.93 \mathrm{~b}$ & $0.60 \mathrm{c}$ & $0.51 \mathrm{~b}$ & $1.11 \mathrm{C}$ & $1.56 \mathrm{~b}$ & $66.45 \mathrm{~b}$ & $1.15 \mathrm{~b}$ & $0.25 b$ \\
\hline$C \vee(\%)$ & 44 & 64 & 4.47 & 3.59 & 9.64 & 17.77 & 10.09 & 28.40 & 23 & 21.14 & 13 \\
\hline Source of Variati & \multicolumn{11}{|c|}{ F Valuec } \\
\hline Substrate (S) & $12.02^{* *}$ & $7 * *$ & ** & $02^{* *}$ & $7^{* *}$ & $72.13^{* *}$ & $5^{* *}$ & $46.21^{* *}$ & $19.22^{* *}$ & $4.37^{*}$ & $87.89 * *$ \\
\hline Dose (D)a & $0.52 \mathrm{~ns}$ & $247.84^{* *}$ & $121.71^{* *}$ & $128.8^{* *}$ & $157.23^{* *}$ & $100.85^{* *}$ & $169.82^{* *}$ & $103.94^{* *}$ & $62.48^{* *}$ & $21.71^{* *}$ & $130.35^{* *}$ \\
\hline$S \times D$ & $2.11^{*}$ & $18.22^{* *}$ & $17.07^{* *}$ & $17.17^{* *}$ & $15.35^{* *}$ & $19.62^{* *}$ & $23.03^{* *}$ & $20.63^{* *}$ & $4.66^{* *}$ & $4.78^{* *}$ & $22.96^{* *}$ \\
\hline
\end{tabular}

Sugar apple seedlings grown in coconut powder showed higher values of number of leaves (>NL), height $(>\mathrm{PH})$, stem diameter (>SD), leaf area index (>LAI), root volume (>RV), shoot dry matter (>SDM), root dry matter (>RDM) and total dry matter (>TDM) and, consequently, higher Dickson quality index (DQI) (Table 2, Figures 1 and 2). On the other hand, considering all variables, sugar apple seedlings grown in fresh sugarcane bagasse, in general, exhibited lower values compared with those produced in enriched sugarcane bagasse, coconut powder and Tropstrato ${ }^{\circledR}$.
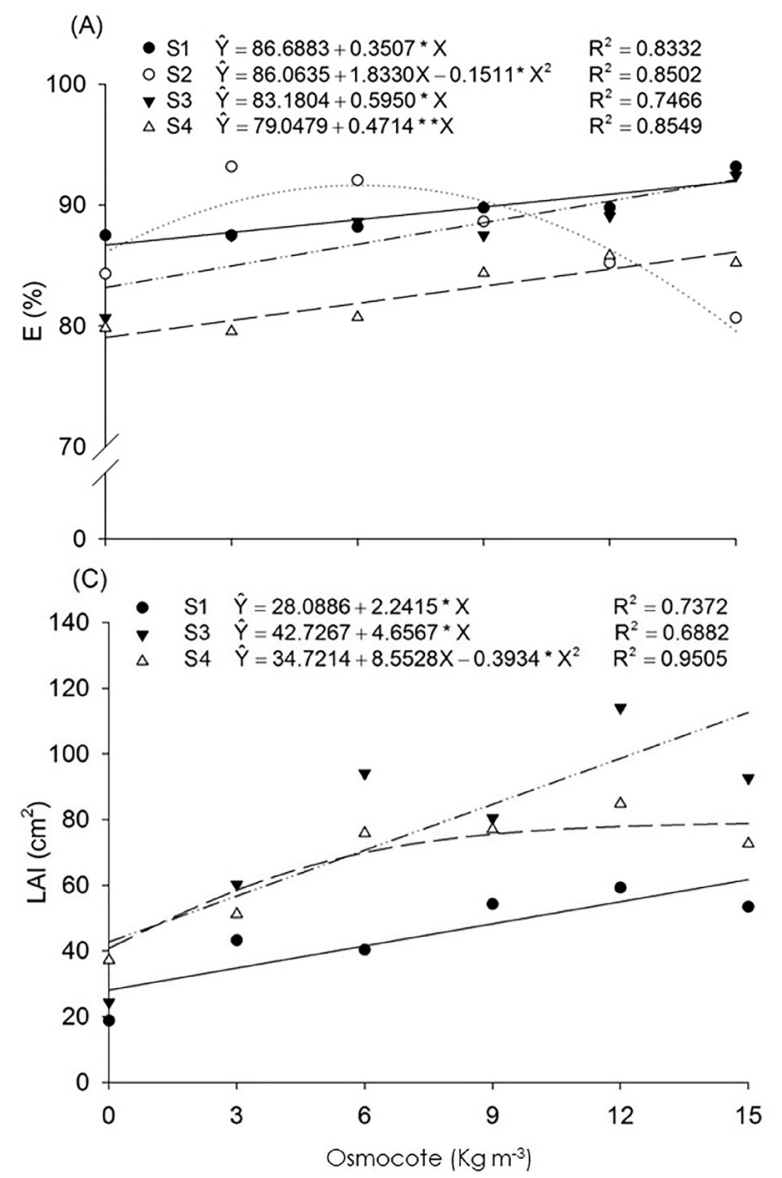

Emergence percentage (E\%) was relatively high for sugar apple and ranged from $86.12 \%$ in plants grown in Tropstrato ${ }^{\circledR}$ to $92.10 \%$ in plants grown in coconut powder (Figure 1A).

For enriched sugarcane bagasse, the highest estimated E\% was $91.62 \%$ at the estimated Osmocote ${ }^{\circledR}$ dose of $6.06 \mathrm{~kg} \mathrm{~m}^{-3}$. For the substrates fresh sugarcane bagasse, coconut powder and Tropstrato ${ }^{\circledR}, E \%$ increased by $6.07,10.73,8.94 \%$, respectively, between the absence of Osmocote ${ }^{\circledR}$ application and its maximum dose (Figure 1A).
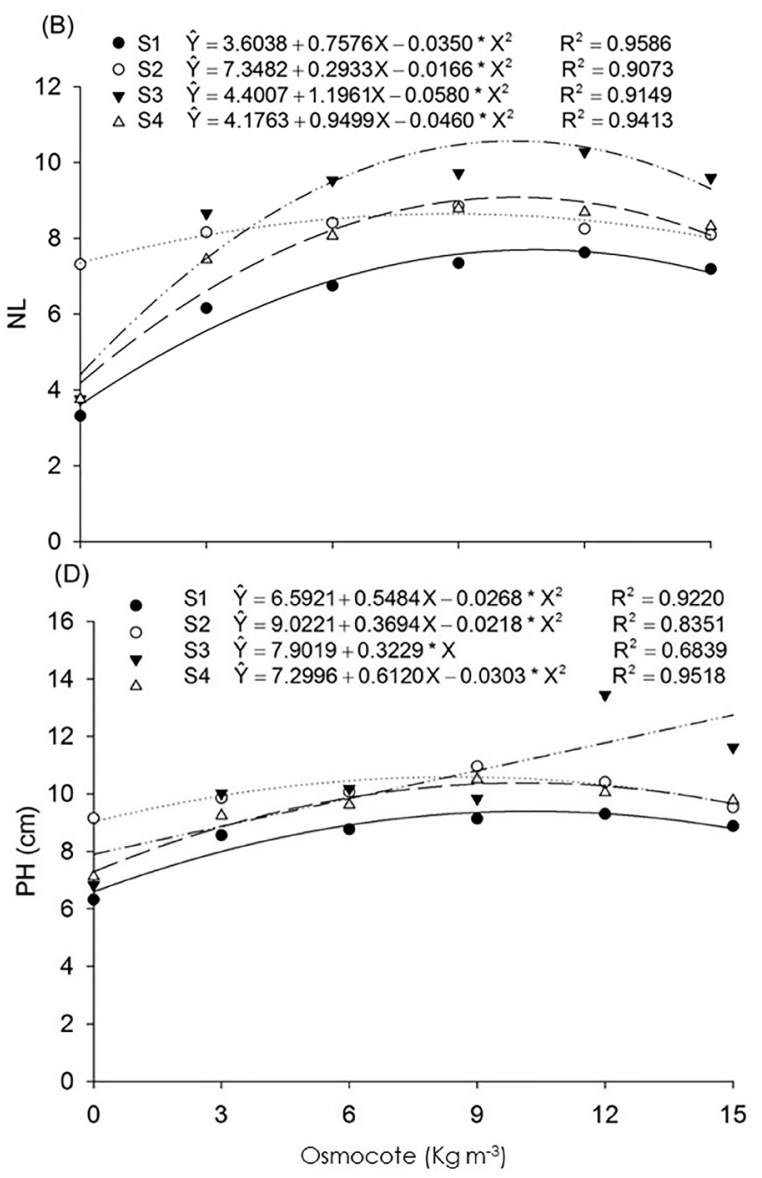

Figure 1. Emergence percentage (E\%) (A), number of leaves (NL) (B), leaf area index (LAI) (C) and plant height (PH) (D) as a function of different substrates and doses of slow-release fertilizer. ${ }^{*},{ }^{* *}$ indicate significant at 0.05 and 0.01 probability levels by t-test, respectively. S1, fresh sugarcane bagasse; S2, enriched sugarcane bagasse; S3, coconut powder; S4, Tropstrato HA Hortaliça ${ }^{\circledR}$. 

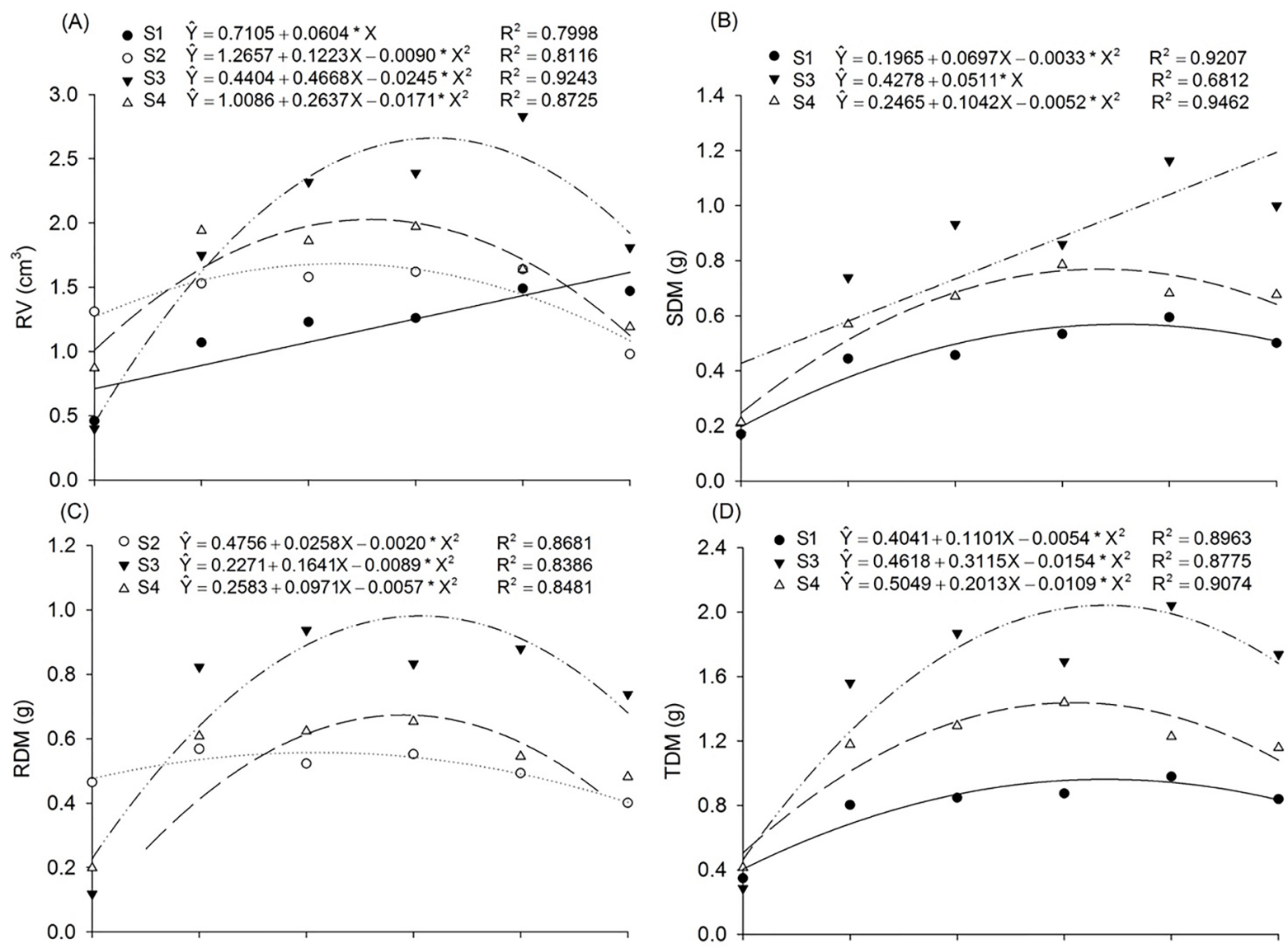

$(\mathrm{E})$
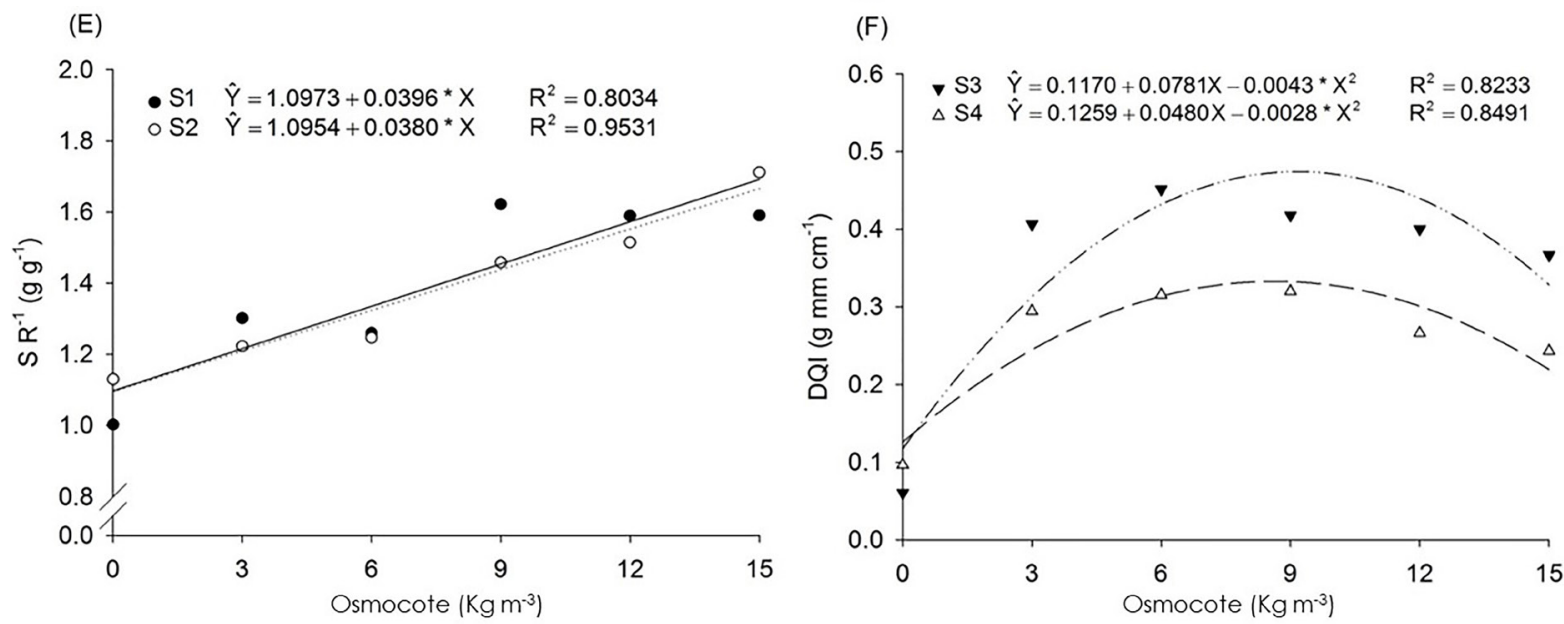

Figure 2. Root volume (RV) (A), shoot dry matter (SDM) (B), root dry matter (RDM) (C), total dry matter (TDM) (D), ratio between shoot and root dry matter $\left(S R^{-1}\right)(E)$ and Dickson quality index (DQI) (F) as a function of different substrates and doses of slow-release fertilizer. *, ** indicate significant at 0.05 and 0.01 probability levels by t-test, respectively. S1, fresh sugarcane bagasse; S2, enriched sugarcane bagasse; S3, coconut powder; S4, Tropstrato HA Hortaliça ${ }^{\circledR}$.

Regarding NL, the doses leading to maximum efficiency in the substrates fresh sugarcane bagasse, enriched sugarcane bagasse, coconut powder and Tropstrato $^{\circledast}$ were 10.82, 8.83, 10.31 and $10.32 \mathrm{~kg} \mathrm{~m}^{-3}$, respectively (Figure $1 \mathrm{~B}$ ), and coconut powder led to the highest NL (10.57). For this substrate, as well as fresh sugarcane bagasse, the highest LAI was obtained only with the maximum dose of Osmocote ${ }^{\circledR}$ (Figure 1C). Similar behavior was observed for $\mathrm{PH}$ in plants grown in the substrate coconut powder (Figure 1D). The other substrates led to maximum PH with estimated Osmocote ${ }^{\circledR}$ doses of 10.23 (fresh sugarcane bagasse), 8.47 (enriched sugarcane bagasse) and $10.10 \mathrm{~kg} \mathrm{~m}^{-3}$ (Tropstrato ${ }^{\circledR}$ ).

The substrate coconut powder promoted higher $\mathrm{RV}$, with maximum estimated value of $2.66 \mathrm{~cm}^{3}$ for the estimated Osmocote ${ }^{\circledR}$ dose of $9.5 \mathrm{~kg} \mathrm{~m}^{-3}$ (Figure 2A).

For SDM, seedlings grown in coconut powder showed increment of about $180 \%$ between the lowest $\left(0.0 \mathrm{~kg} \mathrm{~m}^{-3}\right)$ and highest $\left(15.0 \mathrm{~kg} \mathrm{~m}^{-3}\right)$ doses of slow-release fertilizer (Figure 2B). For the substrates fresh sugarcane 
bagasse and Tropstrato ${ }^{\circledast}$, SDM as a function of Osmocote ${ }^{\circledR}$ doses was lower than that obtained in coconut powder, considering the dose of maximum efficiency of the fertilizer (Figure 2B). The substrate coconut powder also led to higher RDM, TDM and DQI at the estimated Osmocote ${ }^{\oplus}$ doses of $9.22,10.11$ and $9.08 \mathrm{~kg} \mathrm{~m}^{-3}$ (Figures $2 \mathrm{C}, 2 \mathrm{D}$ and $2 \mathrm{~F}$ ).

The fits of the models allowed to visualize increments of 54 and $52 \%$ in S/R between the lowest and highest doses of the fertilizer in the substrates fresh sugarcane bagasse and enriched sugarcane bagasse, respectively (Figure 2E). For the other substrates, there was no fit of $S / R$ as a function of the fertilizer doses.

The analysis of simple correlation between growth variables revealed that NL, PH, SD, LAI, SDM, RDM, $R V$, TDM and DQI were positively correlated. Therefore, it can be claimed that these characteristics are directly proportional, i.e., increment in the value of one of them corresponds to increment in the values of the other characteristics of the sugar apple seedling (Table 3).

Table 3. Correlation between growth variables of sugar apple seedlings as a function of different substrates and doses of slow-release fertilizer

\begin{tabular}{|c|c|c|c|c|c|c|c|c|c|c|c|}
\hline & $\mathrm{Ea}$ & NLb & $\mathrm{PHC}$ & SDd & LAle & SDMf & RDMg & RVh & TDMi & $S / R j$ & DQII \\
\hline$E$ & - & $0.12 \mathrm{~ns}$ & $0.13 \mathrm{~ns}$ & $0.06 \mathrm{~ns}$ & $0.09 \mathrm{~ns}$ & $0.09 \mathrm{~ns}$ & $0.03 \mathrm{~ns}$ & $0.04 \mathrm{~ns}$ & $0.08 \mathrm{~ns}$ & $0.10 \mathrm{~ns}$ & $0.04 \mathrm{~ns}$ \\
\hline $\mathrm{NL}$ & - & - & $0.89^{* *}$ & $0.92 * *$ & $0.82 * *$ & $0.94^{* *}$ & $0.83^{* *}$ & $0.81^{* *}$ & $0.83^{* *}$ & $0.07 \mathrm{~ns}$ & $0.85^{* *}$ \\
\hline $\mathrm{PH}$ & - & - & - & $0.87^{* *}$ & $0.82 * *$ & $0.94^{* *}$ & $0.76 * *$ & $0.78^{* *}$ & $0.76^{* *}$ & $0.11 \mathrm{~ns}$ & $0.75^{* *}$ \\
\hline SD & - & - & - & - & $0.78 * *$ & $0.92 * *$ & $0.87^{* *}$ & $0.79 * *$ & $0.93 * *$ & $0.06 \mathrm{~ns}$ & $0.90 * *$ \\
\hline LAI & - & - & - & - & - & $0.88^{* *}$ & $0.71 * *$ & $0.73^{* *}$ & $0.83^{* *}$ & $0.11 \mathrm{~ns}$ & $0.87^{* *}$ \\
\hline SDM & - & - & - & - & - & - & $0.85^{* *}$ & $0.82 * *$ & $0.97 * *$ & $0.06 \mathrm{~ns}$ & $0.87^{* *}$ \\
\hline RDM & - & - & - & - & - & - & - & $0.87^{* *}$ & $0.96 * *$ & $0.03 \mathrm{~ns}$ & $0.99 * *$ \\
\hline $\mathrm{RV}$ & - & - & - & - & - & - & - & - & $0.88^{* *}$ & $0.22 \mathrm{~ns}$ & $0.85^{* *}$ \\
\hline TDM & - & - & - & - & - & - & - & - & - & $0.15 \mathrm{~ns}$ & $0.96 * *$ \\
\hline$S / R$ & - & - & - & - & - & - & - & - & - & - & $0.34 \mathrm{~ns}$ \\
\hline DQI & - & - & - & - & - & - & - & - & - & - & - \\
\hline
\end{tabular}

\section{Discussion}

The growth and quality of sugar apple seedlings were altered by substrate and dose of the slow-release fertilizer Osmocote ${ }^{\circledR}$. Higher $\mathrm{C} / \mathrm{N}$ ratio and lower total porosity (TP) (26\%) and moisture content (12\%) in the substrate fresh sugarcane bagasse contributed to the lower development of sugar apple seedlings. Higher $\mathrm{C}$ content, in relation to $\mathrm{N}$, may trigger $\mathrm{N}$ immobilization by microorganisms (Livesley et al., 2016) and, consequently, reduce its availability to sugar apple plants. Additionally, reduced moisture and porosity may limit root system development, decreasing the potential of absorption of nutrients by plants.

On the other hand, although a few differences were observed, all substrates lead to high E\% values and, moreover, the slow-release fertilizer was efficient to increase this percentage, evidencing the importance of supplying nutrients in the initial growth stage of sugar apple seedlings.

The fertilizer was also efficient to increase the $\mathrm{NL}$ and LAI of sugar apple seedlings. Its nutritional composition, especially the predominant presence of $\mathrm{N}$, was essential for the increment in the number of leaves and leaf area. Such gain allows greater interception of global solar radiation (Schwerz et al., 2016), which may lead to higher $C$ fixation for the synthesis of carbohydrates in the plants.
The substrate coconut powder showed the best performance for $\mathrm{E} \%, \mathrm{NL}$ and LAI in sugar apple plants, which reinforces its recommendation to be used in seedling production. The physical characteristics of coconut powder (high porosity and water retention potential), and the fact that it is biodegradable and $100 \%$ natural, make it extremely interesting for plant propagation in nurseries.

Coconut powder also allowed higher $\mathrm{PH}$, but at the highest dose of Osmocote ${ }^{\circledR}$. Another important factor that must be highlighted is related to the RV developed by the seedlings grown in coconut powder. RV of 2.66 $\mathrm{cm}^{3}$ for the estimated Osmocote ${ }^{\circledR}$ dose of $9.5 \mathrm{~kg} \mathrm{~m}^{-3}$ may have been essential for the best performance of coconut powder. Increments in RV can substantially favor the access to nutrients and water (Hosseini et al., 2017), contributing to the absorption and translocation of the elements to the shoots (Vromman et al., 2016).

The use of the Osmocote ${ }^{\circledR}$ dose of $9.5 \mathrm{~kg} \mathrm{~m}^{-3}$ dose of maximum efficiency to estimate RV - to estimate the $\mathrm{PH}$ of seedlings subjected to coconut powder led to the value of $10.97 \mathrm{~cm}$, which is even higher than the $\mathrm{pH}$ of seedlings grown in the other substrates. Seedling height is an important biometric feature in the recommendation of the ideal size for definitive planting in the field. However, since plant height can be influenced by possible distortions caused by the excess of $\mathrm{N}$ and also by the competition 
for light (etiolation), it is essential to also consider the tota dry matter of the plant (Marana et al., 2008).

In this regard, good yields of SDM, RDM and TDM were observed in plants grown in coconut powder, which also showed satisfactory results with the addition of slowrelease fertilizer. Good development of leaf tissues, due to fertilization, defines the increment in the photosynthetic capacity of the plants and is directly related to the greater development of the seedlings (Hawerroth et al., 2013).

Besides the search for efficiency in leaf tissue development, it is extremely important to understand the organization and functioning of physiological, growth and development processes of the plants. For that, evaluating the relationship between shoot dry matter and root dry matter may guide the choice of the best substrate and most adequate dose of fertilizer, since the relationship is useful in the study on the balance between organs and is influenced by alterations in many factors, such as temperature, water balance, nutrients and carbon (Machado et al., 2011).

Alterations were observed in the $S / R$ ratio as a function the slow-release fertilizer and substrate, with increasing values due to the addition of Osmocote ${ }^{\circledR}$. Such behavior results from the increase of plant tissue in the shoots, favored by the increment of $\mathrm{N}$ present in the fertilizer.

On the other hand, the substrates did not show similar values of $S / R$. Higher values were observed in seedlings grown in the substrates fresh sugarcane bagasse and enriched sugarcane bagasse. However, higher $S / R$ ratios did not lead to seedlings with superior quality, as evidenced by the DQI of the seedlings in the different substrates.

The DQI values of the plants in all substrates were higher than the minimum index, equal to 0.2, established by Dickson et al. (1960) as indicator of high quality of the seedling for transplantation. The higher the DQI, the better the quality of the produced seedling (Caldeira et al., 2012). Hence, the substrate coconut powder stands out among the most promising ones for the production of good-quality sugar apple seedlings.

Efficiency in the use of the fertilizer Osmocote ${ }^{\circledR}$ has been observed in many crops, including pineapple (Freitas et al., 2011), acai palm (Almeida et al., 2018) and pitanga (Elli et al., 2013). The present study confirms the positive contribution of Osmocote ${ }^{\circledR}$ to the production of sugar apple seedlings. However, as previously discussed, there was interaction between the slow-release fertilizer and the substrate used. Because of that, special attention should be paid in the choice of the material used for plant cultivation.

\section{Conclusions}

Substrate and dose of the slow-release fertilizer Osmocote ${ }^{\circledR}$ had effect on the formation of sugar apple seedlings. Furthermore, the effect of the slow-release fertilizer depends on the substrate used in the formation of sugar apple seedlings. Coconut powder combined with Osmocote ${ }^{\circledR}$ promoted the best performance of the seedlings. Based on the Dickson quality index (DQI), for the production of sugar apple seedlings, we recommend coconut powder associated with the slow-release fertilizer dose of $9 \mathrm{~kg} \mathrm{~m}^{-3}$.

\section{References}

Almeida, L.V.B., Marinho, C.S., Muniz, R.A., Carvalho, A.C.C. 2012. Disponibilidade de nutrientes e crescimento de porta-enxertos de citros fertilizados com fertilizantes convencionais e de liberação lenta. Revista Brasileira de Fruticultura 34: 289-296.

Almeida, U.O., Andrade Neto, R.C., Lunz, A.M.P., Nogueira, S.R., Costa, D.A., Araújo, J.M. 2018. Environment and slowrelease fertilizer in the production of Euterpe precatoria seedlings. Pesquisa Agropecuária Tropical 48: 382-389.

Alvares, C.A., Stape, J.L., Sentelhas, P.C. Moraes, G., Leonardo, J., Sparovek, G. 2013. Köppen's climate classification map for Brazil. Meteorologische Zeitschrift 22: $711-728$.

Basso, C.J. 1999. Épocas de aplicação de nitrogênio para o milho cultivado em sucessão a plantas de cobertura de solo, no sistema plantio direto. $91 \mathrm{f}$. (M.Sc. Thesis) - Federal University of Santa Maria, Santa Maria, Brazil.

Borges, L.C., Ferreira, D.F. 2003. Poder e taxas de Erro Tipo I dos testes Scott-Knott, Tukey e Student-Newmankeuls sob distribuições normal e não normais dos resíduos. Revista de Matemática e Estatistica 21: 67-83.

Caldeira, M.V.W., Delarmelina, W.M., Lübe, S.G., Gomes, D.R., Gonçalves, E.O., Alves, A.F. 2012. Biossólido na composição de substrato para a produção de mudas de Tectona grandis. Floresta 42: 77-84.

Carrijo, O.A., Deliz, R.S., Makishima, N. 2002. Fibra da casca do coco verde como substrato agrícola. Horticultura Brasileira 20: 533-535.

Costa, A.C., Neto, A.C., Ramo, J.D., Borges, D.I. 2011. Alternativas para adubação de porta-enxertos de abacateiro 'quintal' e seu efeito no pegamento de enxertia. Revista Brasileira de Fruticultura 33: 1283-1293.

Dantas, D.J., Mendonça, V., Medeiros, E.V., Góes, G.B., Dantas, D.J. 2010. Superfosfato triplo no crescimento inicial de porta-enxerto de pinheira (Annona squamosa L.). Revista Verde de Agroecologia e Desenvolvimento Sustetável 5: 231-236. 
Delarmelina, W.M., Caldeira, M.V.W., Faria, J.C.T., Gonçalves, E.O., Rocha, R.L.F. 2014. Diferentes substratos para produção de mudas de Sesbania virgata. Floresta e Ambiente 21: 224-233.

Dickson, A., Leaf, A., Hosner, J.F. 1960. Quality appraisal of white spruce and white pine seedling stock in nurseries. Forestry Chronicle 36: 10-13.

Dutra, T. R., Massad, M.D., Sarmento, M.F.Q., Oliveira, J.C. 2012. Emergência e crescimento inicial da canafístula em diferentes substratos e métodos de superação de dormência. Revista Caatinga 25: 65-71.

Elli, E.F., Caron, B.O., Monteiro, G.C., Pavan, M. A., Pedrassanii, M., Cantarelli, E.B., Eloy, E. 2013. Osmocote no desenvolvimento e comportamento fisiológico de mudas de pitangueira. Comunicata Scientiae 4: 377-384.

Freitas, S.J., Carvalho, A.J.C., Berilli, S.S., Santos, P.C., Marinho, C.S. 2011. Substratos e Osmocote® na nutrição e desenvolvimento de mudas micropropagadas de abacaxizeiro cv. Vitória. Revista Brasileira de Fruticultura Special: 672-679.

Hawerroth, F. J., Serrano, L.A.L., Martins, M.V.V., Oliveira, M.M.T. 2013. Doses de adubo de liberação lenta na produção de mudas de pinheira em tubetes. Embrapa Agroindústria Tropical, Fortaleza, Brazil. 21 p.

Hosseini, F., Mosaddeghi, M.R., Dexter, A.R. 2017. Effect of the fungus Piriformospora indica on physiological characteristics and root morphology of wheat under combined drought and mechanical stresses. Plant Physiology Biochemistry 118: 107-120.

Klooster, W.S., Cregg, B.M., Fernandez, R.T., Nzokou, P. 2012. Growth and physiology of deciduous shade trees in response to controlled-release fertilizer. Scientia Horticulturae 135: 71-79.

Livesley, S.J., Ossola, A., Threlfall, C.G., Hahs, A.K., Williams, N.S.G. 2016. Soil Carbon and Carbon/Nitrogen Ratio Change under Tree Canopy, Tall Grass, and Turf Grass Areas of Urban Green Space. Journal of Environmental Quality 45: 215-223.

Malavolta, E., Vitti, G.C., Oliveira, S.A. 1997. Avaliação do estado nutricional das plantas. Princípios e aplicações. Potafos, Piracicaba, Brazil. 319 p.

MAPA. Ministério da Agricultura, Pecuária e Abastecimento (BR). 2007. Instrução Normativa $n^{\circ} 17$, de 21 de maio de 2007: Métodos Analíticos Oficiais para Análise de Substratos e Condicionadores de Solos. Brasília (DF). Available from: http://www.agricultura.gov. br/assuntos/insumos-agropecuarios/insumos-agricolas/ fertilizantes/legislacao/in-31-de-23-10-2008-alterametodo-substrato.pdf. <Access on 12 Feb. 2017>

Marana, J.P., Miglioranza, E., Fonseca, E.P., Kainuma, R.H. 2008. Índices de qualidade e crescimento de mudas de café produzidas em tubetes. Ciência Rural 38: 39-45.

Melo Júnior, J.C.F., Lima, A.M.N., Teixeira, M.V., Conceição, G.C., Santos, L.R. 2014. Depleção de água no substrato e doses de fertilizante Osmocote ${ }^{\circledR}$ na formação de mudas de mamoeiro. Comunicata Scientiae 5: 499-508.

Rodrigues, F.A., Costa, F.H.S., Pasqual, M. 2019. Crescimento de bananeiras micropropagadas em função do substrato e adubo de liberação controlada. Revista de Ciências Agroveterinárias 18: 146-149.

Santos, P.L.F., Paixão, A.P., Silva, O.N.M., Castilho, R.M.M., Faria, R.C., Vieira, N.C.S. 2018. Doses de adubo de liberação lenta no crescimento inicial de mudas de tamarindo. Nucleus 15: 137-146.

Schwerz, F., Caron, B.O., Elli, E.F., Oliveira, D.M., Monteiro, G.C., Souza, V.Q. 2016. Avaliação do efeito de doses e fontes de nitrogênio sobre variáveis morfológicas, interceptação de radiação e produtividade do girassol. Revista Ceres 63: 380-386.

Serrano, L.A.L., Cattaneo, L.F., Ferreguetti, G.A. 2010. Adubo de liberação lenta na produção de mudas de mamoeiro. Revista Brasileira de Fruticultura 32: 874-883.

Silva, D.J., Queiroz, A.C. 2002. Análises de alimentos (métodos químicos e biológicos). UFV, Viçosa, Brazil. 235 p.

Silva, R.P., Peixoto, J.R.I., Junqueira, N.T.V. 2001. Influência de diversos substratos no desenvolvimento de mudas de maracujazeiro azedo (Passiflora edulis Sims f. flavicarpa DEG). Revista Brasileira de Fruticultura 23: 377-381.

Vale, F.X.R., Fernandes Filho, E.I., Liberato, J.R., Zambolim, L. 2001. Software Quant - Quantificação de doenças. Version 1.0.1. UFV, Viçosa, Brazil. CD-ROM.

Vromman, D., Lefèvre, I., Šlejkovec, Z., Martínez, J-P., Vanhecke, N., Briceño, M., Kumar, M., Lutts, S. 2016. Salinity influences arsenic resistance in the xerohalophyte Atriplex atacamensis Phil. Environmental and Experimental Botany 126: 32-43.

Conflict of Interest Statement: The authors declare that the research was conducted in the absence of any commercial or financial relationships that could be construed as a potential conflict of interest.

All the contents of this journal, except where otherwise noted, is licensed under a Creative Commons Attribution License attribuition-type BY. 